\author{
Katarzyna Sicińska \\ Uniwersytet Łódzki \\ Instytut Filologii Polskiej i Logopedii \\ ORCID: 0000-0003-4080-1497; e-mail: katarzyna.sicinska@uni.lodz.pl
}

\title{
Archaiczność polszczyzny południowokresowej. Zagadnienia teoretyczno-metodologiczne
}

\begin{abstract}
Abstrakt: W artykule został omówiony problem archaiczności polszczyzny południowokresowej. Przedstawiono podstawy teoretyczne zagadnienia archaiczności odmian terytorialnych języka (teoria falowa J. Schmidta, poglądy neolingwisty włoskiego M. G. Bartoliego). Zreferowano wyniki badań autorów polskich na temat archaizmów i innowacji w kontekście centrum i peryferii językowych: T. Milewskiego, Z. Stiebera, H. Popowskiej-Taborskiej. Na tym tle przedstawiono cechy archaiczne polszczyzny południowokresowej w odniesieniu do XVII-XVIII wieku. Zwrócono uwagę na problemy metodologiczne oraz interpretacyjne dotyczące funkcjonowania archaizmów w tej odmianie języka (konieczność zastosowania metod językoznawstwa konfrontatywnego oraz historyczno-porównawczego, trudność w odróżnieniu archaizmu od zapożyczenia).
\end{abstract}

Słowa kluczowe: polszczyzna południowokresowa, archaizm językowy, peryferie etniczno-językowe, interferencja.

\begin{abstract}
The archaic nature of the Polish language in the southern part of Eastern Borderland. Theoretical and methodological issues. The author discusses the issue of the archaic nature of the Polish language spoken in the southern part of Eastern Borderland. She presented the theoretical basis of the archaic quality of the territorial variants of the language (J. Schmidt's wave theory, the opinions of M. G. Bartoli, an Italian neo-linguist ). The results of the research into archaisms and innovations in the context of the centre and peripheries of the language by Polish authors T. Milewski, Z. Stieber and H. Popowska-Taborska, have also been presented. Against this background, the archaic features of the Polish language spoken in the southern part of Eastern Borderland were presented with reference to the $17^{\text {th }}$ and $18^{\text {th }}$ centuries. Attention has been drawn to the methodological and interpretational problems of archaisms in this variant of the language (the requirement of using historic-comparative and confrontational linguistic methods, the difficulty with distinguishing archaisms and loan-words).
\end{abstract}

Keywords: Polish language in the southern part of Eastern Borderland, language archaism, ethnic and linguistic peripheries, interference.

Polszczyzna południowokresowa należy do historycznych odmian terytorialnych języka polskiego ${ }^{1}$. Zaczęła się kształtować w XIV-XV w. na południowo-wschodnich rubieżach dawnego państwa polskiego, następnie przez stulecia odgrywała rolę istotnego środka komunikacji społecznej w I Rzeczypospolitej, wpływając m.in. na kształt

${ }^{1}$ Na temat statusu kresowej odmiany języka polskiego zob. Sicińska 2020. 
polskiego języka literackiego, a ostatecznie swoją naturalną żywotność i rozwój zakończyła w połowie XX w. Momentem przełomowym stały się wydarzenia II wojny światowej, które położyły kres istnieniu południowokresowej wspólnoty komunikatywnej. Współcześnie polszczyzna południowokresowa ma charakter reliktowy a jej przyszłe losy pozostają niepewne ${ }^{2}$.

Od innych wariantów geograficznych języka polskiego odróżnia polszczyznę południowokresową w sposób zasadniczy geneza. Odmiana ta uformowała się bowiem poza granicami etnicznej Polski, na terenie Rusi Czerwonej, Podola, Wołynia i Kijowszczyzny, wchodzących niegdyś w skład I Rzeczypospolitej, czyli na obszarze określanym jako Kresy Południowo-Wschodnie ${ }^{3}$. Ze względu na zasięg występowania była to więc odmiana peryferyczna, kształtująca się z dala od polskiego centrum etniczno-językowego, a ponadto pozostająca $\mathrm{w}$ nieustannym kontakcie $\mathrm{z}$ innym językiem etnicznym, występującym na tych terenach, mianowicie językiem ruskim (ukraińskim). Na jej powstanie złożyły się dwa procesy: polonizacja wyższych warstw społeczeństwa ruskiego, a tym samym nakładanie się polskiego superstratu na ruski (ukraiński) substrat językowy, oraz przeniesienie języka polskiego przez osadników z Małopolski, Mazowsza i innych regionów Polski na tereny ruskie (ukraińskie), a tym samym podleganie przez polszczyznę wpływom adstratowym ruszczyzny (języka ukraińskiego).

Od końca XIX w. począwszy aż po czasy współczesne polszczyzna dawnych Kresów Południowo-Wschodnich cieszy się dużym zainteresowaniem językoznawców, a literatura poświęcona różnym aspektom i okresom jej funkcjonowania tworzy wcale pokaźny zbiór ${ }^{4}$. W opracowaniach poświęconych tejże odmianie pojawia się stały pogląd, stanowiący już swego rodzaju communis opinio dialektologii historycznej, iż peryferyczność polszczyzny południowokresowej skutkuje jej archaicznością. Zachowanie dawnych cech językowych, wypartych poza normę języka literackiego, na obszarach oddalonych od centrum etniczno-językowego postrzegane jest jako jeden z wyznaczników peryferyczności wszelkich odmian językowych.

Źródłem tezy o archaiczności peryferii językowych i o istnieniu archaizmów peryferycznych jest teoria falowa (niem. Wellentheorie) niemieckiego językoznawcy Johannesa Schmidta. W myśl owej teorii każda zmiana językowa powstaje w określonym miejscu, w określonym punkcie geograficznym, z którego rozchodzi się następnie w otoczeniu w sposób koncentryczny, na coraz większych obszarach. Proces ten przypomina rozchodzenie się fal na powierzchni wody po wrzuceniu do niej kamienia (zob. Heinz 1983, 172-173). Punkt, w którym powstała innowacja językowa, to centrum, a obrzeża obszaru objętego zmianą to peryferie językowe. Rozprzestrzenianie się zmian przebiega w kierunku od centrum do peryferii, zaś dynamika procesu największa jest

${ }^{2}$ O prognozach dotyczących żywotności bądź też zaniku polszczyzny kresowej zob. Rieger 2019; Zielińska 2003.

3 Przez Kresy Południowo-Wschodnie rozumiem południowo-wschodnie województwa Rzeczypospolitej Obojga Narodów, czyli województwa: ruskie, podolskie, wołyńskie, bracławskie, kijowskie (województwo siewierskie należało do państwa polskiego jedynie przez 33 lata, od 1635 do 1667 r., w związku z czym trudno brać je pod uwagę). Szerzej na temat pojęcia Kresów zob. Sicińska 2013, 17-45.

${ }^{4}$ Stan badań nad tą odmianą polszczyzny zawierają m.in. następujące prace: Dzięgiel 2003; Krasowska 2015; Sawaniewska-Mochowa 1991; 1995; Sicińska 2013, 49-55, 69-72; 2018c. 
właśnie w centrum, słabnie zaś w miarę oddalania się od niego. Słabnąca tendencja może nie dotrzeć na obszary peryferyczne, na których zachowują się w związku z tym cechy wcześniejsze, starsze, czyli archaizmy (Mańczak 1970, 232; Długosz-Kurczabowa, Dubisz 2006, 73).

Idea zawarta w teorii falowej Schmidta znalazła swoją kontynuację w poglądach neolingwistów włoskich i francuskich, zwłaszcza w pracach włoskiego romanisty Matteo Giulio Bartoliego, twórcy szkoły neolingwistycznej. W publikacji z 1925 r. Bartoli sformułował pięć zasad, zwanych przez niego normami, które w założeniu mają służyć określaniu chronologii względnej zjawisk językowych. Należy zwrócić uwagę zwłaszcza na dwie spośród nich. Pierwsza zakłada, że na izolowanych terenach danego języka narodowego występuje większe nasilenie zjawisk archaicznych niż w jego centrum, stanowiącym obszar wspólnotowy. Wprawdzie zdaniem Witolda Mańczaka zasada ta nie stanowi żadnego novum, ponieważ językoznawcom wiadomo było od dawna, że gwary występujące na obszarach trudno dostępnych, np. na wyspach, obszarach bagnistych czy w górach itp., mają charakter archaiczny, niemniej należy przyznać, że wskazana zależność jest słuszna i możliwa do prostego wyjaśnienia (Mańczak 1970, 229-233).

Drugą istotną z punktu widzenia archaizmów tezę Bartoliego współtworzą dwa poglądy szczegółowe. Pierwszy (właściwa norma Bartoliego) głosi, że jeśli zjawisko A występuje na krańcach obszaru językowego, a zjawisko B w centrum tegoż obszaru, to zjawisko A jest na ogół starsze od B. Drugi pogląd, będący uzasadnieniem owej normy, sprowadza się do sądu, że innowacje powstają częściej w centrum obszaru językowego niż na jego krańcach, co jest równoznaczne z twierdzeniem, że obszary peryferyczne mają charakter bardziej archaiczny od obszarów centralnych (Mańczak 1970, 232). Witold Mańczak dowodzi, że sama „norma” Bartoliego jest słuszna (gdyż potwierdzają ją liczne przykłady), natomiast uzasadnienie normy jest błędne, nie ma bowiem żadnych powodów, dla których innowacje miałyby się pojawiać częściej w centrum niż na obszarach peryferycznych (badacz udowadnia to na przykładzie leksyki języków romańskich; Mańczak 1970, 232-238).

Niezależnie od tego, jakie stanowisko przyjmiemy w kwestii norm Bartoliego, istnienie archaizmów peryferycznych pozostaje niezaprzeczalnym faktem. Zdaniem Mańczaka nie można zaprzeczyć istnieniu archaizmów peryferycznych, należy jednak odrzucić przekonanie, że języki lub gwary używane na peryferii danego obszaru mają charakter bardziej archaiczny od języków lub narzeczy występujących w centrum tegoż obszaru. Skoro jednak archaizmy peryferyczne istnieją, ich występowanie musi mieć jakąś przyczynę. Badacz tłumaczy ów fakt rachunkiem podobieństwa: bardziej prawdopodobne jest, że spośród dwu różnych wyrazów, z których jeden występuje w centrum, a drugi na peryferii, ten peryferyczny występował niegdyś na całym obszarze, a centralny jest rezultatem innowacji, niż to, że oba te wyrazy są rezultatami dwu niezależnych, paralelnych innowacji, które wyszły z dwu różnych punktów (Mańczak 1970, 235 i inne; por. też Mańczak 1996, 178; Mańczak 2007, 280).

W językoznawstwie polskim problem relacji archaizmów i innowacji do peryferii i centrum obszarów etnicznych znalazł się w kręgu zainteresowań Tadeusza Milewskiego. Jako punkt wyjścia badacz przyjął założenie propagowane przez neolingwistów, iż innowacje biorą początek w centrum obszaru etnicznego, zaś na peryferiach ulegają całkowitemu lub częściowemu wygaszeniu. Na podstawie zasięgu siedmiu procesów 
fonetycznych różnicujących obszar prasłowiański, takich jak metateza, przejście samogłosek nosowych w ustne, zwężenie wymowy ě do $e$ (lub nawet $\dot{e}$ czy $i$ ), przejście psł. $y$ w $i$ (lub dźwięk zbliżony do $i$ ), zanik prasłowiańskich intonacji, dyspalatalizacja spółgłosek miękkich przed samogłoskami przednimi, przejście $g \mathrm{w} h$, próbował określić centrum Słowiańszczyzny. Zdaniem autora, wszystkie wymienione procesy dokonały się późno, między VIII a XII w., a więc już po rozpadzie wspólnoty prasłowiańskiej, zaś centrum, z którego się one rozszerzały na dalsze tereny, leżało na południe od Karpat. Peryferie, do których omawiane tendencje nie dotarły lub dotarły, ale słabo się na nich zaznaczyły, to obszary słoweńsko-czakawskie i południoworuskie (peryferie bliższe), obszary północnoruskie i polskie (peryferie średnie) oraz obszary bułgarsko-macedońskie i połabsko-pomorskie (peryferie dalekie) (Milewski 1965, 135-137).

Hipotezę dotyczącą archaizmów peryferycznych rozwinął następnie Zdzisław Stieber (1974). Badacz przytoczył na jej poparcie różnorodne przykłady. W zakresie Słowiańszczyzny wskazał przede wszystkim zachowanie zwartego $g$ na obszarze trzech wielkich peryferii słowiańskich, tj. w językach z grupy lechicko-dolnołużyckiej, północnorosyjskiej i południowosłowiańskiej. W centrum słowiańskiego obszaru językowego, czyli na obszarach czesko-słowackim, górnołużyckim, ukraińskim i białoruskim oraz w dialektach południoworosyjskich i północno-zachodnich dialektach słoweńskich, a także w części czakawskich zaszła natomiast w XII-XIII w. zmiana zwartego $g$ na szczelinowe $h$. W zakresie polszczyzny jako wyrazisty archaizm peryferyczny jawi się zdaniem Stiebera zachowanie bifonematycznej wymowy $\check{r}$ na Kaszubach i na południowym zachodzie Polski. Innowacja centralna polegająca na zmianie $\check{r}$ na $\check{z}$ lub $\check{s}$ na te peryferie nie dotarła (Stieber 1974, 239).

Jednocześnie jednak badacz zwrócił uwagę, że obok archaizmów peryferycznych istnieją także innowacje peryferyczne. W ten sposób Stieber zakwestionował, krytykowane również przez Mańczaka, przekonanie, iż innowacje szerzą się z obszarów centralnych, zaś archaizmy utrzymują się głównie na peryferiach różnych obszarów językowych. Jako przykład innowacji peryferycznej z obszaru Słowiańszczyzny podał Stieber zmianę krótkich samogłosek $i, u$ w ,szwa” w dialekcie kaszubskim oraz $\mathrm{w}$ dialektach słoweńskich (Stieber 1974, 240). Inną bardzo wyrazistą zdaniem badacza innowacją peryferyczną jest powstanie szeregu $\check{s}, \check{z}, \check{c}$, $\check{\delta}$ wskutek spłynięcia się szeregów $\check{s}, \check{z}, \check{c}, \check{\delta}$ oraz $\dot{s}, \dot{z}, \dot{c}, \dot{\delta}$, charakterystyczne dla trzech małych peryferii: gwar jabłonkowskich na pograniczu polsko-czeskim w Cieszyńskiem, gwar lubawskich na północy Polski oraz południowego pasa dialektu wschodniosłowackiego. Obszarem centralnym jest w stosunku do owych peryferii zwarty obszar niemazurzących gwar polskich oraz przyległy pas gwar czeskich oraz sąsiadujące z polskimi gwary ukraińskie i większość dialektu wschodniosłowackiego (Stieber 1974, 240).

Problematykę archaizmów i innowacji oraz ich relacji do centrum i peryferii podjęła w swoich pracach także Hanna Popowska-Taborska, zarówno w odniesieniu do Słowiańszczyzny (w związku z badaniami nad etnogenezą Słowian; m.in. Popowska -Taborska 1980b; 1981), jak i w odniesieniu do polskiego obszaru etnicznego (Popowska-Taborska 1986).

Inspiracją do rozważań nad tą drugą kwestią, czyli nad zagadnieniem centrum i peryferii w świetle archaizmów i innowacji na polskim obszarze językowym stało się dla Popowskiej-Taborskiej opublikowanie Atlasu polskich innowacji dialektalnych Karola 
Dejny. To dzięki temu „opracowaniu przedstawiającemu w plastyczny sposób zasięgi wszystkich istotnych zachodzących na polskim obszarze językowym innowacji fonetycznych, akcentowych, słowotwórczych i fleksyjnych" możliwy stał się przegląd zasięgów cech archaicznych i innowacyjnych (Popowska-Taborska 1986, 173). Autorka przeprowadziła analizę wielu zjawisk.

W zakresie zjawisk archaicznych wskazała: osiemnaście archaizmów peryferycznych na polskim obszarze językowym (m.in. kaszubskie tart $<$ tort i utrzymanie się miękkości spółgłosek przed 'ar $<\dot{r} T$; zachowanie frykatywnego $\check{r}$ charakterystyczne dla peryferii północnych oraz spotykane w bardzo ograniczonych zasięgach na peryferii zachodniej i południowo-zachodniej; zachowanie miękkości wargowych w wygłosie ogarniające znaczną część północno-zachodnią i pojawiające się reliktowo na Kaszubach; brak przejścia $i>y$ po stwardniałym frykatywnym $\check{r}$, charakteryzujący kraniec

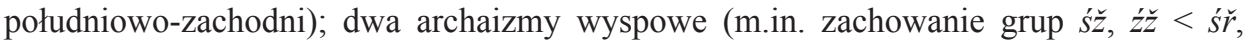
$z ́ r$ ); kilka archaizmów tworzących układ dwudzielny: archaizm-innowacja, dzielących obszar mniej więcej na połowę; jeden i to nieco wątpliwy archaizm centralny (zachowanie form z 3 w wyrazach zban, zbanek) (Popowska-Taborska 1986, 173-175).

Wśród innowacji badaczka wymieniła: pięć cech innowacyjnych o bardzo szerokich zasięgach terytorialnych, zajmujących prawie cały polski obszar językowy i będących odwrotnością faktów archaicznych o zasięgu peryferycznym (m.in. formy ze stwardniałą spółgłoską przed ar < *ŕrT); siedemnaście innowacji peryferycznych (np. kaszubski zanik ruchomego $e \mathrm{w}$ bezkońcówkowych formach rzeczowników z przyrostkiem -ek, -ec; wyodrębnienie $i$ przed spółgłoskami palatalnymi, obejmujące zachodni kraniec Polski); siedem faktów innowacyjnych związanych z reguły z peryferycznymi obszarami, lecz mających znacznie większe zasięgi (m.in. rozłożenie miękkich wargowych na grupy spółgłoskowe, obejmujące Polskę północną oraz w określonych wypadkach sięgające po centrum; przejście $\chi>f$ (kraniec Małopolski południowo-wschodniej) i $\chi>k$ (typowe dla krańca południowej Małopolski, lecz zaświadczone też na znacznie większym obszarze Polski południowo-zachodniej); fakty innowacyjne obejmujące peryferie, ale występujące też w centrum (zjawiska zbliżone do poprzedniej kategorii; np. zatrata dwuwargowego $w$ i związane $z$ nią dalsze konsekwencje fonetyczne), zjawiska innowacyjne zajmujące w przybliżeniu połowę obszaru, podczas gdy drugą część cechuje stan bardziej archaiczny (np. stwardnienie staropolskiego l’ przed $i$ zajmujące całą Polskę północno-wschodnią); innowacje, które występują na obszarach zwartych, a dodatkowo też w rozproszeniu na pozostałych terenach (np. uproszczenie grup stř $t \check{r}, z d \check{r}, d \check{r}$ na $\check{s} \check{c}, \check{c}, \check{z} \check{\delta}, \check{\delta}$ charakterystyczne dla peryferii zachodniej i południowej, a notowane też sporadycznie na pozostałym obszarze); nieliczne innowacje o zasięgu centralnym, tzn. niewystępujące na peryferiach (przede wszystkim mazurzenie oraz zastępowanie sufiksu bezokolicznika -eć przez - 'ić || -yć) (Popowska-Taborska 1986, 175-178).

Po przeanalizowaniu wielu zjawisk dialektalnych autorka doszła do wniosku, że materiał językowy z polskiego obszaru językowego: po pierwsze, mocno podbudowuje tezę o istnieniu archaizmów peryferycznych oraz w zasadzie zaprzecza istnieniu archaizmów centralnych, niespotykanych na peryferiach obszaru, po drugie, pozwala mówić o licznych innowacjach peryferycznych, po trzecie wreszcie, ukazuje problem innowacji centralnych jako zagadnienie znacznie bardziej skomplikowane, niż to się zwykło 
przedstawiać (Popowska-Taborska 1986, 178-179). Autorka wyraziła zarazem przekonanie, że kaszubszczyzna z racji swego peryferycznego położenia jest bardziej archaiczna od polskiego języka literackiego (Popowska-Taborska 1980a).

Wątek archaizmów peryferycznych oraz nasilonej archaiczności obszarów peryferycznych w stosunku do obszarów centralnych przywoływany jest też w wielu pracach dotyczących polszczyzny kresowej, zajmującej położenie peryferyczne wśród pozostałych odmian języka. Są to przede wszystkim prace Zofii Kurzowej i Józefa Kościa.

Zofia Kurzowa proces wytworzenia się polszczyzny kresowej jako nowej, odrębnej odmiany językowej o zasięgu terytorialnym ograniczonym do terenów ruskich przedstawiała w wielu swoich opracowaniach. W skrócie pogląd badaczki można ująć następująco: język polski przeniesiony na obce (ruskie) tereny etniczne, na peryferie ówczesnego państwa polskiego, rozwijał się następnie w oderwaniu od polszczyzny terenów rdzennych, nakładając się na obce podłoże językowe, czyli na substrat ukraiński, a zarazem podlegając jego wpływom adstratowym (związanym z sąsiedztwem), wytwarzał przy tym własne, swoiste cechy innowacyjne oraz konserwował pewne cechy archaiczne, usunięte poza obręb normy ogólnopolskiej (zob. m.in. Kurzowa 1997, 126-128).

W szczegółach proces ten badaczka przedstawiała następująco:

Związki dialektu południowokresowego z polskim superstratem przejawiały się, z jednej strony, jako kontynuacja wszystkich starych, systemowo ważnych cech polskich, jak np. rozwój psł. grup tolt, tort, psł. sonantów, polskich przegłosów, samogłosek nosowych, dawnych jerów, z drugiej zaś - jako wspólna z językiem literackim, choć może nieco wolniejsza, ewolucja w kierunku przystosowania się do polskich, literackich norm językowych.

Wspólny rozwój dialektu kresowego z językiem literackim napotykał jednak dwie przeszkody: oddalenie terytorialne od centrum etnicznie polskiego oraz obce otoczenie, które sprawiało, że ogólnopolskie normy językowe nie były nigdy wyraziście uświadamiane przez użytkowników, a dążenie do nich wywoływało wiele hiperpoprawności.

Usytuowanie na peryferiach państwa polskiego oddalało dialekt od głównego rozwojowego nurtu językowego i nadawało mu pewne znamiona archaiczności. Natomiast powiązanie dialektu z ruskim substratem polegało na wchłanianiu pewnych cech ruskich, lecz nie starych i ważnych w rodzaju pełnogłosu, $l$ epentetycznego, ikawizmu, braku miękkości przed dawnym $e$, ale nowych, fonetycznie aktualnych i żywych, jak np. redukcja i ścieśnienia samogłosek nieakcentowanych, dźwięczny krtaniowy fonem $h$, dwuwargowa wymowa $w$, wprowadzanie na miejsce polskich połączeń $x y, x e, k e$, ruskich $x$ 'i, x'e, k'e i inne [...].

Polszczyzna południowokresowa ewoluowała więc zgodnie z ogólnymi tendencjami polszczyzny literackiej, natomiast nawiązywała do ruskiego podłoża poprzez pewien zasób cech zapożyczonych, które w tej samej liczbie i w tej samej dystrybucji utrzymywały się w południowokresowym dialekcie przez wieki.

Ruski substrat $\mathrm{i}$ adstrat językowy nie tylko wprowadziły do dialektu pewien zasób obcych elementów językowych. Zderzenie się w mowie jednostek dwóch systemów, polskiego i ruskiego, wytworzyło w nim cechy innowacyjne, nie znane ani polszczyźnie, ani ruszczyźnie. Występowały one w postaci różnego rodzaju form analogicznych, uproszczonych i hiperpoprawnych.

W ciągu wielu wieków dialekt południowokresowy rozwinął w swoim systemie wiele cech osobliwych z punktu widzenia normy ogólnopolskiej, dających się sprowadzić do 
trzech typów: archaizmów, ukrainizmów oraz innowacji na wszystkich płaszczyznach syste$\mathrm{mu}^{5}$ (Kurzowa 1997, 127-128).

Temat archaiczności polszczyzny południowokresowej rozwinął następnie w swoich pracach Józef Kość (2000). Badacz stwierdza, że regionalny wymiar polszczyzny południowokresowej jako odmiany peryferycznej wyraża się w archaiczności, czyli dłuższej egzystencji cech archaicznych, a zarazem w innowacyjności na różnych poziomach języka. Archaiczność i innowacyjność stanowią zatem dwa bieguny osi rozwojowej polszczyzny południowokresowej, przy czym, co niezmiernie istotne, oba zjawiska mogą mieć charakter albo niezależny, albo stymulowany przez presję języka ukraińskiego jako substratu/adstratu (w językach blisko spokrewnionych mamy do czynienia z paralelnym rozwojem tych samych elementów językowych) (Kość 2000, 453).

Warto zaznaczyć, że cechy innowacyjno-archaiczne stanowią jeden z podstawowych wyróżników odmian językowych używanych przez wspólnoty komunikatywne poza granicami kraju. Taki zestaw cech dowodzi, zdaniem Stanisława Dubisza, tezy o samodzielnym rozwoju polszczyzny poza granicami państwa etnicznego (Dubisz 1999, 91; 2000, 170).

Przyjrzyjmy się teraz bezpośrednio polszczyźnie południowokresowej pod kątem obecnych w niej cech archaicznych. Przykłady dotyczyć będą jej stanu z XVII i XVIII wieku.

Do cech archaicznych polszczyzny południowokresowej, którym można przyznać status regionalizmów funkcjonalnych w stuleciach XVII i XVIII, zaliczymy następujące właściwości:

a) na poziomie fonetycznym: miękka realizacja $l \mathrm{w}$ pozycji przed samogłoskami innymi niż $i$, np. alie, poufalie (w odniesieniu do XVIII w.); wolniejsze identyfikowanie się $r$ frykatywnego $(\check{r}) \mathrm{z} \check{z}$, tj. utrzymywanie się bifonematycznej wymowy $\check{r}^{6}$; formy typu kożdy (dla XVIII w.), jako, dopioro; brak joty w formach typu przydzie (w odniesieniu do XVII-XVIII w.) oraz ociec, mieśce (w odniesieniu do XVIII w.);



b) w zakresie słowotwórstwa: pojedyncze formacje, które w dobie średniopolskiej wychodziły lub wyszły z użycia jako jednostki leksykalne, podlegały zmianom semantycznym lub strukturalnym; nieliczne przykłady tego typu stanowią czasowniki prefiksalne: poranić 'zabrać się do czego rano, wstać rano', wyzwać 'pozwać do sądu' (Sicińska 2013, 409);

c) w zakresie fleksji: końcówka -ej w dopełniaczu, celowniku i miejscowniku lp. rzeczowników żeńskich miękkotematowych, np. okazyjej, nadziejej; archaiczne formy przypadków zależnych zaimka nico, np. wniwecz, wniwczym; dawne formy zaimka on

\footnotetext{
5 Model typologiczny cech polszczyzny południowokresowej, na który składają się archaizmy, zapożyczenia ukraińskie (jako rezultat interferencji języka ludności autochtonicznej), innowacje niezależne, a także, co należy dodać, dialektyzmy, wraca także w późniejszych opracowaniach (zob. m.in. Sicińska 2013).

${ }^{6}$ Warto przypomnieć, że zachowanie bifonematycznej wymowy $\check{r} \mathrm{~W}$ gwarach kaszubskich oraz na południowym zachodzie Polski jest też postrzegane jako archaizm na terenach etnicznie polskich (Stieber 1974, 239; Popowska-Taborska 1986, 173).
} 
tworzone od tematu on-, np. onego ${ }^{7}$, końcówka -am w celowniku 1.mn. rzeczowników rodzaju żeńskiego, np. zakonnicam; dominacja końcówki -emy nad -imy (-ymy) w 1. os. Im. czasowników koniugacji -ę, -isz (-ysz) zarówno w XVII, jak i w XVIII w., np. musiemy (Kość 1999, 81-82, 100-101; Sicińska 2013, 253-254);

d) w zakresie skladni: podmiot $\mathrm{w}$ mianowniku przy orzeczeniu wyrażającym istnienie zaprzeczone, np. zeby [...] Condemnata nie była; dominowanie w XVIII w. mianownika w pozycji orzecznika przymiotnego wbrew tendencji do szerzenia się narzędnika, np. Ja do wszytkiego jestem gotowy; dopełnienie porównawcze w dopełniaczu z przysłówkiem w stopniu wyższym (składnia genetivus comparationis), np. gorzej zdrajców i przekonanych złoczyńców, gorzej nieprzyjacieli krzyża; składnia biernikowa przy czasowniku wiedzieć, np. abym wiedział dyspozycja Jego, wiedząc krzywdę Ojca mego; okolicznik miary wyrażony dopełniaczem po przysłówku w stopniu wyższym (składnia genetivus comparationis), np. więcej czterech niedziel; okolicznik miejsca $\mathrm{w}$ postaci wyrażenia $w+$ biernik zastąpiony później wyrażeniem do + dopełniacz, np. $w$ dom odestać, wystać $w$ Trojanów; zastosowanie przyimka $w$ w znaczeniu 'do', np. $w$ dom (Sicińska 2013, 336);

e) w zakresie leksyki: mieszanie znaczeń czasowników wiedzieć i znać (Sicińska 2013, 451).

Na utrzymanie się części wymienionych archaizmów w polszczyźnie południowokresowej wpłynął zapewne język ukraiński, w którym funkcjonują analogiczne formy i konstrukcje. Do kategorii archaizmów wspartych interferencją języka ukraińskiego należą:

a) na poziomie fonetyki: zachowanie miękkiego $l$ 'oraz bifonematycznej wymowy $\check{r}$;

b) w zakresie słowotwórstwa: zachowanie czasownika poranić;

c) w zakresie fleksji: końcówka -am w celowniku 1. mn. rzeczowników rodzaju żeńskiego;

d) w zakresie składni: składnia genetivus comparationis po przysłówkach w stopniu wyższym (wyrażenia występujące w funkcji dopełnienia lub okolicznik miary); składnia biernikowa przy czasowniku wiedzieć;

e) w zakresie leksyki: mieszanie znaczeń czasowników wiedzieć i znać.

Problem funkcjonowania archaizmów w polszczyźnie południowokresowej łączy się więc $\mathrm{z}$ kwestią interferencji językowych. Ewokuje to niejednokrotnie trudności w rozpoznaniu naczelnego czynnika sprawczego danego zjawiska językowego, a ponadto wymaga stosowania $\mathrm{w}$ badaniach tej odmiany języka metod językoznawstwa konfrontatywnego oraz metody historyczno-porównawczej (zob. Sicińska 2018b).

Archaiczne kresowizmy południowe muszą być zawsze rozpatrywane w określonej perspektywie chronologicznej, ponieważ status danego zjawiska podlega zmianie w czasie, jest zależny od stanu rozwojowego języka etnicznego. I tak na przykład miękka realizacja $l \mathrm{w}$ pozycji przed samogłoskami innymi niż $i$ może być traktowana jako archaizm o funkcji regionalizmu dopiero w odniesieniu do XVIII w., ponieważ w stuleciu wcześniejszym relikty miękkiej wymowy zdarzały się w tekstach z różnych regionów Polski (zob. Sicińska 2013, 164-165). Zarazem jest to taki rodzaj archaizmu,

7 Szerzej o tych trzech archaizmach peryferycznych z zakresu fleksji imiennej mowa jest w odrębnym artykule (Sicińska 2016). 
który utrzymuje się w tej odmianie polszczyzny po dziś dzień (zob. m.in. Dzięgiel 2003, 148; Kurzowa 1983, 90-91; 2006, 347; Lehr-Spławiński 1914, 45; 1966, 134).

Zdarza się, że jakaś archaiczna właściwość polszczyzny południowokresowej charakteryzuje się na różnych etapach jej rozwoju rozbieżnym zakresem, co skłania badaczy do odmiennej kwalifikacji i oceny przyczyn zjawiska. Przykładem może być wspomniana już miękka wymowa $l$ przed samogłoskami innymi niż $i$. Zapisy wskazujące na taką właśnie realizację głoski, np. polie, liata, w niedzielie, występują licznie w różnego typu tekstach z XVII i XVIII w. (zob. Kosyl 1978, 116; Kość 1999, 76, 98; Rykiel 1963, 34; Sicińska 2013, 164; Wiśniewska 1975, 35), a ponieważ wymowa taka istniała w polszczyźnie ogólnej do połowy XVI w., cechę tę należy uznać w odniesieniu do XVII, a zwłaszcza XVIII w., za archaizm peryferyczny polszczyzny południowokresowej, na którego podtrzymanie wpłynął język ukraiński (w jego systemie istnieje tylko miękka głoska l). Większość badaczy dwudziestowiecznej polszczyzny południowokresowej również traktuje ten typ wymowy jako archaiczny (zob. m.in. Dzięgiel 2003, 148; Kurzowa 1997, 129). Obserwacja odmiennego zakresu zjawiska może jednak prowadzić do odmiennych wniosków. I tak T. Lehr-Spławiński stwierdził występowanie w Galicji Wschodniej miękkiego $l$ w pozycji przed $i$ oraz przed dawną jotą, np. sol'i, rol'a, l’ulka, ale nie przed e, np. lekki, daleko, co pokrywa się z zakresem miękkiego $l \mathrm{w}$ języku ukraińskim, w którym $l$ przed $e$ przeszło $\mathrm{w} t$. To zaś dało autorowi podstawę do wniosku, iż miękkie $l$ jest wynikiem wpływów ukraińskich (Lehr -Spławiński 1914, 45; 1966, 134)8. Przykład miękkiego $l$ dowodzi także, jak trudno niekiedy odróżnić archaizm od zapożyczenia.

Niekiedy z punktu widzenia dzisiejszej normy językowej dana właściwość nie jawi się ani jako regionalizm, ani jako archaizm, a tymczasem w dawnej epoce miała charakter regionalnego archaizmu w stosunku do szerzącej się, lecz efemerycznej, ostatecznie nieutrwalonej w języku innowacji. Na przykład w niektórych tekstach południowokresowych z XVIII w. obserwuje się dominację mianownika w pozycji orzecznika przymiotnego typu do wszystkiego jestem gotowy, jestem bardzo umartwiony. $\mathrm{Na}$ tle ówczesnej polszczyzny, w której szerzył się w tej pozycji narzędnik, wycofany z końcem XIX w., właściwość tę możemy postrzegać jako archaiczną (zob. Sicińska 2013, 268-269).

Polszczyzna południowokresowa jako odmiana terytorialna o skomplikowanej i odmiennej w stosunku do pozostałych wariantów geograficznych języka genezie wykształciła szczególne cechy systemowe. Brak łączności z polszczyzną terenów etnicznych oraz wpływy substratowe i adstratowe języka ruskiego (ukraińskiego) zadecydowały o dwóch przeciwstawnych tendencjach rozwojowych tej odmiany: innowacyjności oraz archaiczności. Innowacyjność wyrażała się zarówno w wytwarzaniu cech nowych, swoistych wskutek wewnętrznej ewolucji językowej, ale też w postaci zapożyczeń z języka ukraińskiego będących efektem procesów interferencyjnych (regionalizmy kontaktowe). Była to więc innowacyjność o różnorakiej proweniencji. Archaiczność, polegająca na konserwowaniu cech dawnych, miała charakter zjawiska niezależnego jako skutek oddalenia od centrum innowacji (archaizmy peryferyczne), albo też stymulował ją wpływ

\footnotetext{
${ }^{8} \mathrm{Na}$ temat rozbieżności interpretacyjnych dotyczących tej i innych właściwości polszczyzny południowokresowej zob. Sicińska 2018a.
} 
języka ukraińskiego (podtrzymywanie cech archaicznych polszczyzny dzięki ich analogicznemu rozwojowi w blisko spokrewnionym języku ukraińskim). Na kwestię owego opozycyjnego układu cech regionalnych zwracają uwagę liczni badacze polszczyzny kresowej, nie tylko jej odmiany południowej, ale i północnej (Kość 2000; Kurzowa 2006; Nowowiejski 1996, 51-52; Urbańczyk 1979, 210). Choć należy zaznaczyć, że odmiana południowa rozwijała się mimo wszystko w większej łączności z rdzennym językiem polskim (dzięki bliższym związkom terytorialnym dawnych Kresów Południowo-Wschodnich, zwłaszcza Rusi Czerwonej, z terenami etnicznej Polski), przez co nie była ani tak konserwatywna, ani tak archaiczna jak odmiana północna (por. Dzięgiel 2003, 85; Kurzowa 1983, 68-72; 2006, 19-42; Rieger 2001, 582-585).

\section{Literatura}

Długosz-Kurczabowa K., Dubisz S. (2006), Gramatyka historyczna języka polskiego, Warszawa.

Dubisz S. (1999), Status polszczyzny Kresów pólnocno-wschodnich wobec języka innych polonocentrycznych wspólnot komunikatywnych poza granicami kraju, „Acta Baltico-Slavica” 24, s. 87-93.

Dubisz S. (2000), Regionalizmy w polszczyźnie poza granicami kraju, [w:] Kultura, język, edukacja, t. 3, red. R. Mrózek, Katowice, s. 167-172.

Dzięgiel E. (2003), Polszczyzna na Ukrainie. Sytuacja językowa w wybranych wsiach chłopskich $i$ szlacheckich, Warszawa.

Heinz A. (1983), Dzieje językoznawstwa w zarysie, Warszawa.

Kosyl C. (1978), Właściwości fonetyczne polszczyzny kresowej w 1. połowie XVIII wieku (na przykładzie języka mieszczan hrubieszowskich), „Studia z Filologii Polskiej i Słowiańskiej”, t. 17 , s. $105-121$.

Kość J. (1999), Polszczyzna południowokresowa na polsko-ukraińskim pograniczu językowym $w$ perspektywie historycznej, Lublin.

Kość J. (2000), Archaizmy a interferencje w strefie polsko-ukraińskich kontaktów językowych, „Slavia Orientalis”, t. 49, nr 3, s. 451-462.

Krasowska H. (2015), Stan badań nad polszczyzna południowokresowa. Przeszłość i perspektywy badawcze, [w:] Język polski i polonistyka w Europie Wschodniej: przeszłość $i$ wspótczesność, red. I. Bundza, E. Kowalewski, A. Krawczuk, O. Slyvynskij, Kijów, s. 55-68.

Kurzowa Z. (1983), Polszczyzna Lwowa i kresów poludniowo-wschodnich do 1939 roku, Warszawa-Kraków.

Kurzowa Z. (1997), Historia i wspótczesność języka polskiego na Kresach południowo-wschodnich, [w:] Historia i wspótczesność języka polskiego na Kresach Wschodnich, red. I. GrekPabisowa, Warszawa, s. 111-165.

Kurzowa Z. (2006), Język polski Wileńszczyzny i kresów pólnocno-wschodnich XVI-XX w., [w:] Z. Kurzowa, Prace językoznawcze, t. 2, wybór i oprac. M. Szpiczakowska, M. Skarżyński, Kraków.

Lehr-Spławiński T. (1914), O mowie Polaków w Galicji Wschodniej, „Język Polski” 2, z. 2-3, s. $40-51$. 
Lehr-Spławiński T. (1966), Wzajemne wpływy polsko-ruskie w dziedzinie językowej, [w:] T. Lehr-Spławiński, Studia i szkice wybrane z językoznawstwa słowiańskiego, seria 2, Warszawa, s. $130-142$.

Mańczak W. (1970), Z zagadnień językoznawstwa ogólnego, Wrocław-Warszawa-Kraków.

Mańczak W. (1996), Problemy językoznawstwa ogólnego, Wrocław-Warszawa-Kraków.

Mańczak W. (2007), Rzekoma archaiczność obszarów peryferycznych, „Jezikoslovni zapiski” 2007, 13, 1-2, s. 279-283.

Milewski T. (1965 [1966]), Archaizmy peryferyczne obszaru prasłowiańskiego, „Sprawozdania z Posiedzeń Komisji PAN", Oddział w Krakowie, s. 134-137.

Nowowiejski B. (1996), Kresowizm - co to takiego?, [w:] Wilno i Kresy pótnocno-wschodnie, t. 3, Polszczyzna kresowa, red. E. Feliksiak, B. Nowowiejski, Białystok, s. 43-61.

Popowska-Taborska H. (1980a), Kaszubszczyzna. Zarys dziejów, Warszawa.

Popowska-Taborska H. (1980b), Problem poludniowostowiańskiej peryferii językowej $w$ dociekaniach nad etnogeneza Stowian, [w:] Etnogeneza i topogeneza Stowian, red. I. Kwilecka, Poznań, s. 55-63.

Popowska-Taborska H. (1981), Połabszczyzna jako pótnocno-zachodnia peryferia Stowiańszczyzny, [w:] Stowiańszczyzna połabska między Niemcami a Polska, red. J. Strzelczyk Poznań, s. $95-108$.

Popowska-Taborska H. (1986), Problematyka centrum i peryferii obszaru etnicznego $w$ świetle archaizmów $i$ innowacji dialektalnych (na podstawie analizy obszaru polskiego), „Acta Universitatis Lodziensis. Folia Linguistica" 12, s. 171-180; [przedruk w:] PopowskaTaborska H. (2004), Z językowych dziejów Stowiańszczyzny, Warszawa, s. 269-277.

Rieger J. (2001), Język polski na Wschodzie, [w:] Wspótczesny język polski, red. J. Bartmiński, Lublin, s. 575-590.

Rieger J. (2019), Szanse przetrwania czy odrodzenia się polszczyzny kresowej, „Prace Filologiczne", t. LXXIII, s. 343-368.

Rykiel B. (1963), O języku Wilczków - mieszczan lwowskich XVII wieku, „Poradnik Językowy”, z. 1 , s. 32-39.

Sawaniewska-Mochowa Z. (1991), Bibliografia prac o polszczyźnie kresowej, [w:] Studia nad polszczyzną kresowa, t. 6, red. J. Rieger, W. Werenicz, Wrocław-Warszawa-Kraków, s. 223254.

Sawaniewska-Mochowa Z. (1995), Bibliografia prac o polszczyźnie kresowej za lata 1989-1993 (z uzupetnieniami do roku 1988), [w:] Studia nad polszczyzna kresowa, t. 8, red. J. Rieger, Warszawa, s. 265-282.

Sicińska K. (2013), Polszczyzna poludniowokresowa XVII i XVIII wieku (na podstawie epistolografii), Łódź.

Sicińska K. (2016), Archaizmy fleksyjne w polszczyźnie poludniowokresowej XVII i XVIII wieku, [w:] Dawne z nowym taczac... In memoriam Mariani Kucała, red. J. Klimek-Grądzka, M. Nowak, Lublin, s. 39-55.

Sicińska K. (2018a), Dylematy interpretacyjne badacza dawnej polszczyzny poludniowokresowej, [w:] Historia języka w XXI wieku. Stan i perspektywy, red. M. Pastuch, M. Siuciak, przy współpracy K. Wąsińskiej, W. Wilczek, Katowice, s. 415-435.

Sicińska K. (2018b), Jak badać polszczyznę potudniowokresowa XVII i XVIII wieku? Z problemów metodologicznych dialektologii historycznej, [w:] Metodologie językoznawstwa. Od diachronii do panchronii, red. P. Stalmaszczyk, Łódź, s. 11-42. 
Sicińska K. (2018c), Z historii badań nad polszczyzna południowokresowa XVII i XVIII wieku, [w:] Historia języka, dialektologia i onomastyka w nowych kontekstach interpretacyjnych, red. R. Przybylska, M. Rak, A. Kwaśnicka-Janowicz, Kraków, s. 289-302.

Sicińska K. (2020), O statusie $i$ nazewnictwie odmian języka polskiego na dawnych Kresach Wschodnich, „Prace Filologiczne”, t. LXXV, część 2, s. 200-220, https://doi.org/10.32798/ pf.468.

Stieber Z. (1974), O archaizmach i innowacjach peryferycznych, [w:] Studia indoeuropejskie. Études indo-européennes, red. J. Kuryłowicz, Wrocław, s. 239-241.

Urbańczyk S. (1979), Przyczyny zaniku samogłosek pochylonych w języku polskim, [w:] S. Urbańczyk, Prace z dziejów języka polskiego, Wrocław, s. 265-277.

Wiśniewska H. (1975), Polszczyzna przemyska wieków XVII-XVIII, Wrocław.

Zielińska A. (2003), Czy polszczyzna pótnocnokresowa ma szanse przetrwania? (w świetle koncepcji dyglosji $i$ żywotności etnolingwistycznej ethnolinguistic vitality), „Acta BalticoSlavica”, s. 97-109. 